Coming Home Again: Johannes Hofer, Edmund Spenser, and Premodern Nostalgia

\title{
Alex Davis
}

The word 'nostalgia' was coined by the Swiss medical student Johannes Hofer in his 1688 Dissertatio Medica de Nostalgia, oder Heimwehe. Hofer's treatise and Edmund Spenser's 1595 poem Colin Clovts Come home againe exemplify a premodern nostalgia. Hofer moves between moments of familiarity and alienation, whilst Spenser's poem offers a richly imaginative response to the Elizabethan attempt to 'plant' new homes in Ireland. In each case, premodern nostalgia situates the longing for home within patterns of doubling and repetition that unsettle ideas of origin and belonging even as they propagate them.

Suppose we were wanderers who could not live in blessedness except at home, miserable in our wandering and desiring to end it and return to our native country. We would need vehicles for land and sea which could be used to help us to reach our homeland, which is to be enjoyed. But if the amenities of the journey and the motion of the vehicles itself delighted us, and we were led to enjoy the things which we should use, we should not wish to end our journey quickly, and, entangled in a perverse sweetness, we should be alienated from our country, whose sweetness would make us blessed.

Augustine, Of Christian Doctrine ${ }^{1}$

It isn't what it used to be. Most commentators note that at its point of origin the term 'nostalgia' denoted a geographical longing for one's native land, and not a longing for a lost past; also that it originally emerged within medical discourse, as a disease rather than as an aesthetic or existential affect. These observations are accurate. Yet by positioning premodern nostalgia as the predecessor to its modern descendants, such formulae deploy a nostalgia of their own, flattening the specificity of the past into a simple template which can then be used as a benchmark against which to measure off present complexities. This essay looks at two premodern treatments of nostalgia, the 1688 treatise by Johannes Hofer that coined the word, and Edmund Spenser's 1595 poem Colin Clovts Come home againe. It takes its cue from the conventional pleonasm that marks Spenser's title: to 'come home again', used to speak of a single return and not a series of homecomings. In each case, I argue, Hofer and Spenser frame nostalgic longing within structures of doubling and repetition that disclose within the desire to return home a kind of plurality such as subtly complicates our sense of what home is, or might be, and of the meanings that might attach to a premodern nostalgia. Traditionally, nostalgia has been understood as a by-product of the transformations and novelties of modernity. This essay argues for its role as an agent within them, as it goes on to explore the relationship between Spenser's poem and the scenes of violence and displacement that mark his participation in the Elizabethan effort to extend English power throughout Ireland. In this way, the

1 Augustine of Hippo, On Christian Doctrine, trans. D. W. Robertson, Jr. (Indianapolis: The Liberal Arts Press, 1958), pp. 9-10. 
psychic and physiological structures that Johannes Hofer describes, and the complex entanglements of alienation and belonging that mark Spenser's verse, can be seen as moments within a larger constellation of historical shifts within which nostalgic affect has been put to work: caught up within a modernity that now appears not simply as loss but as a process of home-making that, however, is every bit as violently wasteful as it is productive, foundational, or creative.

The Swiss medical student Johannes Hofer's Dissertatio Medica de Nostalgia, oder Heimweh was printed in 1688. It describes a curious disorder, often found in young men and women sent abroad-Hofer mentions soldiers, students and household servants-particularly characteristic of the Swiss but present in other peoples, in which the sufferer is consumed by a desire for his or her native land. Hofer's nostalgics suffer from an 'afflicted imagination', focused upon this one idea to the exclusion of all others. ${ }^{2}$ The result is a potentially fatal disturbance of the patient's psychic and physical health, which Hofer proposes to call nostalgia. Nostalgia, for Hofer, is a longing for home. Yet at the very moment of the concept's explicit formulation, nostalgia emerges out of a complex articulation of ideas of belonging, blurring the outlines of this apparently straightforward definition.

We might start, as Hofer does, with questions of language. His is a Dissertatio Medica de Nostalgia, oder Heimwehe - that is, a 'Medical Dissertation on Nostalgia, or Homesickness'. Why not just the latter term, since it already existed? The Dissertatio begins by discussing this decision, in ways that subtly foreground the centrality of language to belonging. Hofer's treatise is written in Latin and its key term is a Greek neologism, but it opens with an account of nostalgia's vernacular competitors. Hofer writes that 'Heimweh' is a word which 'the gifted Helvetians have introduced not long since into their vernacular language, chosen from the grief for the lost charm of the Native Land'. Similarly, 'since the Helvetians in Gaul (France) were taken often by this mood, among that same nation it merited the name la Maladie du Pays' (p. 380). The 1688 printing of the Dissertatio emphasises this movement between languages typographically, alternating between Roman type for Hofer's Latin text, Greek characters when discussing the etymology of nostalgia, and a large, emphatic blackletter for German. Notably, blackletter is not used for French in the original edition of the Dissertatio, even though both are contemporary vernaculars (one might contrast Carolyn Anspach's modern translation of Hofer, which italicises both French and German). ${ }^{3}$ Heim, for the Swiss writer, is distinctive; it is the language of home. ${ }^{4}$ Later, Hofer offers the case study of a country girl who suffered a fall and was taken to hospital. Upon returning to consciousness she refused all medicine, 'groaning nothing else than "Ich will heim; Ich will heim"' (p. 383). In this episode,

\footnotetext{
${ }^{2}$ For a translation, see Johannes Hofer, 'Medical Dissertation on Nostalgia by Johannes Hofer, 1688', trans. Carolyn Kiser Anspach, Bulletin of the Institute of the History of Medicine, 2 (1934), 376-91 (p. 381). Further references appear parenthetically. For the Latin text, see Dissertatio Medica de Nostalgia, oder Heimwehe (Basel: Jacobus Bertschius, 1688); this edition is mis-dated on the titlepage to 1678 .

${ }^{3}$ I have reintroduced the distinction Anspach effaces in my quotations above.

4 The peoples of the Swiss Confederacy, personified as 'Helvetia', were predominately German-speaking in the seventeenth-century.
} 
the vernacular might be construed as subordinate on a variety of fronts: female, rural, ignorant, irrational. Such a reading is consistent with the Dissertatio's rejection of 'Heimweh'. Yet 'Ich will heim' breaks through Hofer's Latin with great simplicity and force, and Hofer's point is that this appeal cannot and must not be denied. Hofer introduces the Swiss 'Heimweh' into medical discourse, first renaming it as 'nostalgia', then classifying it and offering an account of the aetiology of the disorder. His final point, however, is in a sense anti-medical, to the extent that the Dissertatio rejects treatments based upon specialised professional expertise. The way to cure the nostalgic is simply to take him or her home.

And what of 'nostalgia' itself? Hofer says that he is proposing the coinage because the phenomenon he is discussing 'lacks a particular name in medicine' ( $p$. 380). This thought reflects the increasing importance of taxonomy to seventeenthcentury medical discourse. As Helmut Illbruck has explained, Hofer classified the symptoms he was investigating as a 'wasting disease', giving them a 'visible place in a scientific order'; and by naming them as 'nostalgia', he located them within a larger discursive regime. ${ }^{5}$ In this sense, the function of the neologism was to furnish a home for the new concept. Then there is the meaning of the term. Hofer writes that 'nostalgia' is

composed of two sounds, the one of which is Nostos, return to the native land; the other, Algos signifies suffering or grief; so that thus far it is possible from the force of the sound nostalgia to define the sad mood originating from the desire to return to one's native land. (p. 381$)^{6}$

'Nostalgia' thus borrows the compound form of the word Hofer rejects, since it is, quite transparently, modelled upon Heimweh as Heim or home, plus Weh, woe. ${ }^{7} \mathrm{We}$ might note how curiously emphatic Hofer is about 'nostalgia' as a sonic construct: it is 'composed of two sounds', and it is the 'force of the sound' that delivers the meaning of the word. ${ }^{8}$ The temptation must be to think that Hofer's neologism offers, as he says, a definition - that is, meaning — whereas the vernacular embodies nostalgia at the level of sound rather than signification, since its patterns of articulation sound familiar (or, perhaps, do not sound unfamiliar) to native speakers. 'Heimweh' is just redolent of home to Helvetian ears, certainly when set against some incomprehensible neo-Greek coinage. Yet Hofer's fantasy seems to have been that 'nostalgia' too might signify at the level of sound, like one's mother tongue. However unrealistic that aspiration might have been, it underlines the fact that the concept of nostalgia emerges out of an interplay between the native and the exotic at the level of language. Hofer also proposes 'nosomania' and 'philopatrodomania' as alternatives to his favoured term, whilst a 1710 revision of the Dissertatio replaced 'nostalgia' with a third option,

\footnotetext{
${ }^{5}$ Helmut Illbruck, Nostalgia: Origins and Ends of an Unenlightened Disease (Evanston: Northwestern University Press, 2012), pp. 38, 29.

${ }^{6}$ I have modified Anspach's translation, which gives 'Nosos' for 'Nostos', having misrecognised a printer's contraction.

${ }^{7}$ As Illbruck points out, 'nostalgia' fails to follow the format of authentic Greek compounds such as 'glossalgia', in which the modifier pinpoints the bodily location of the pain. We get instead the pain caused by dislocation. See Illbruck, p. 5.

${ }^{8}$ See Hofer, Dissertatio, sig. A3r: 'duabus ex vocibus compositum' and 'ex vi vocis'.
} 
'pothopatridalgia'.9 'Luckily,' Svetlana Boym comments, these substitutes 'failed to enter common parlance'. ${ }^{10}$ But this relief is only an artefact produced by acceptance of the word. In many ways the tongue-twisting unfamiliarity of its competitors tells the truth about the origins of nostalgia better than nostalgia itself now can: namely, that it is - even as it parasitises features from the vernacular term that it hopes to dislodge - an utterly outlandish way of describing the desire to return to the familiar.

Something similar happens with Hofer's description of the physical aspects of nostalgic longing. Nostalgia is a disease of the imagination, but for Hofer it is not a purely psychic phenomenon. As Helmut Illbruck has demonstrated, Hofer was influenced by the new seventeenth-century sciences of the human body. Innovative anatomists such as Thomas Willis had opened out the brain and nervous system to disclose a landscape as wild and intricate as anything to be found in the outside world: Willis refers to 'the anfractuous or crankling brain, like a plot of ground, planted every where with nooks and corners, and danks and mole-hills'. ${ }^{11}$ This account of the anatomy of the brain was construed as a matter of absolute novelty. Aiming 'to unlock the secret places of Mans Mind' (p. 51), Willis insisted that 'I have not trod the paths or footsteps of others, nor repeated what hath been before told' (p. 125). At the same time, however, repetition and familiarity were central to his account of the relationship between physiological structure and mental event. The peculiar 'crankling' channels that marked the brain served, Willis theorised, to direct and regularise the flow of animal spirits and hence underpinned key psychological faculties:

For as the animal Spirits, for the various acts of Imagination and Memory, ought to be moved within certain and distinct limited or bounded places, and those motions to be often iterated or repeated through the same tracts or paths: for that reason, these manifold convolutions and infoldings of the brain are required for these divers manners of ordinations of the animal Spirits, to wit, that in these Cells or Store-houses severally placed, might be kept the species of sensible things, and as occasion serves, may be taken from thence. (p. 92) ${ }^{12}$

These claims form the background to Johannes Hofer's discussion of nostalgic sickness. There is, we should note, absolutely no rigorously experimental underpinning to Hofer's account of nostalgia. Neither servants nor soldiers were dissected in the course of his research, and he frankly admits that his paper is grounded in anecdote, 'cases and histories' (p. 382). Hofer's references to the new sciences of the brain in some ways merely serve, like the neologism 'nostalgia', to

\footnotetext{
${ }^{9}$ Dissertatio Medica de Pothopatridalgia. Vom Heim-Wehe in Theodor Zwinger ed. Fasculus Dissertationeum Medicarum Selectiorum (Basel: John Ludovic Koenig, 1710).

${ }^{10}$ Svetlana Boym, The Future of Nostalgia (New York: Basic Books, 2001), p. 3.

${ }^{11}$ Thomas Willis, Five treatises viz. 1. Of urines, 2. Of the accension of the blood, 3. Of musculary motion, 4. The anatomy of the brain, 5. The description and use of the nerves. (London: T. Dring, C. Harper, J. Leigh, and S. Martin, 1681), p. 92. Further references appear parenthetically.

${ }^{12}$ On Willis' localisation of the imagination in the 'callous body' of the brain, see Katherine E. Kickel, Novel Notions: Medical Discourse and the Mapping of the Imagination in Eighteenth-Century English Fiction (New York and London: Routledge, 2007), pp. 32-35.
} 
legitimise his thought within an institutional discourse. However, they also open out a striking imaginative terrain within which the idea of nostalgia can take root. The Dissertatio places a strong emphasis upon the material structures of the brain as receptacles for psychic experience. We read of 'the oval tubes of the centre brain' ( $p$. 381); of its 'pores and tubes' (p. 385); and of 'the quite continuous vibration of animal spirits through those fibres of the middle brain in which impressed traces of ideas of the Fatherland still cling' (p. 384). Hofer accepts the importance of habituation in shaping mental activity. The pores of the brain are enlarged by the passage of animal spirits; the spirits then more readily travel down those pathways (p. 385). And so Hofer's account of nostalgia once again emerges out of a peculiar dialectic of familiarity and estrangement. On the one hand, nostalgia is novelty. It is produced by the movement of the animal spirits 'along uncommon routes through the untouched courses of the channels of the brain to the body' (p. 381); hence arises 'the uncommon and ever-present idea of the recalled native land in the mind' (p. 381). On the other hand and at the same time, nostalgia is - as the oxymoronic formulation 'uncommon and ever-present' already suggests - a matter of habituation. ${ }^{13}$ Hofer refers to those who have 'exercised the imaginative element of the mind about the same object and have accustomed their spirits frequently to pursue those same paths' (p. 385). The endpoint of this process is stagnation: the animal spirits cease to move, 'languor of the whole arises, circulation of the blood loses vigor ... and becomes denser and thus apt to receive coagulation, the heart by moving sluggishly and by distending the vessel, generates anxieties' (p. 387). In extreme cases, death may result. The nostalgic's predicament is not so much that he misses home, but that this longing has become so habitual as to erode the mobility of the nervous system considered as a whole. Nostalgic desire is the product of a wilful parochialism at work within the extraordinary new pathways of the brain discovered by Willis and others. It is alienation grown familiar.

\section{II.}

When is a house a home? First printed in 1595, Edmund Spenser's poem Colin Clovts Come home againe (hereafter Colin Clout) opens with a letter of dedication to Walter Raleigh, signed 'From my house of Kilcolman the 27. Of December. 1591'. ${ }^{14}$ The subscription is apt: Colin Clout is a poem to which questions of home and belonging are central. Spenser had been resident in Ireland since 1580, when he was appointed as Secretary to Lord Grey, the Lord Deputy of Ireland. He had occupied Kilcolman castle in the colonial settlement or plantation of Munster since late 1588; in 1590 he was formally granted title to the estate. But was this house a home-that is, an appropriate object of nostalgia - and what might be at stake in claiming it as such? Hofer's new disease was to present itself as a strange amalgam of innovation and stagnation, novelty and repetition. Spenser's poem produces a similar effect in relation to the scenes of colonial dispossession that pervaded Elizabethan Ireland.

These questions are approached via the poem's pastoral fiction. We begin with a homecoming. Colin Clout has been identified by Colin Burrow as an English

\footnotetext{
${ }^{13}$ See Hofer, Dissertatio, sig. A3v: 'unicam [et] ... perpetuam'.

${ }^{14}$ Colin Clovts Come home againe, in Edmund Spenser, The Shorter Poems, ed. Richard A. McCabe (London: Penguin, 1999), deciation. Further references appear parenthetically.
} 
epibaterion or 'celebration of a return home'. ${ }^{15}$ (We might recall Hofer's definition of nostalgia in relation to a 'return to the native land', directing our attention not just to a place, but to the passage towards it.) Colin Clout has returned to his community of shepherds after a voyage abroad. His friend Hobbinol begs him to tell the story of his travels, and Colin is eager to do so, since all his pleasure is now tied up in recollections of Cynthia, queen of the court across the sea:

... since I saw that Angels blessed eie,

Her worlds bright sun, her heauens fairest light,

My mind full of my thoughts satietie,

Doth feed on sweet contentment of that sight:

Since that same day in noght I take delight,

$\mathrm{Ne}$ feeling haue in any early pleasure,

But in remembrance of that glorious bright,

My lifes sole bliss, my hearts eternall threasure. (11. 40-47)

Colin's thoughts feed obsessively upon this remembered 'sight'. Cynthia is a sun, a light, 'glorious bright'. Everything else seems dim; it provokes 'no feeling'. Revisiting the happy image produces pleasure. It also (we infer) propagates the ailment that afflicts Colin. The past has eradicated the present, and Colin's only nourishment lies in recollection.

Colin Clout's symptoms in many ways anticipate those described by Johannes Hofer. Just as in Hofer, we have the dominating idea; we have the suggestion of a disruption of ordinary corporeal processes (Colin 'feeds' on thought alone); and we have the strongly visual character of the obsession-both Hofer's nostalgic and Spenser's Colin Clout are consumed by images and sights that profoundly unsettle their spectator. Most strikingly, in both Hofer's Dissertatio and in Colin Clout, longing is described as a kind of bliss. Nostalgics, Hofer explains, resemble 'those who, rapt in ecstasy from profound meditation, feel little, nor see those present, nor hear them ... for even if their senses are twitched by these external motions, nevertheless these minds occupied by outside things give heed least of all to those motions' (p. 385). So too with Colin, who is said to be possessed by a 'celestiall rage / Of loue' (11. 823-24). But there is one crucial difference. Spenser's poem anticipates the structure of feeling that Hofer explores, but it does so whilst reversing its topographical underpinnings. For the absence that excites Colin Clout's imagination lies not at home but abroad.

Or so it seems at first glance. In fact, Hofer's nostalgia is not an inappropriate concept to evoke once we probe beneath the surface of Spenser's fiction. As every critic recognises, Colin Clout operates as some kind of authorial surrogate for Edmund Spenser in this poem. Colin had already featured in Spenser's Shepheardes Calender, published in 1579. Now his biography begins to track Spenser's own. Born in London, Spenser had lived in Ireland since 1580, an active participant in the Elizabethan effort to 'plant' and settle the land. In 1589 he temporarily returned to England, probably in the company of Walter Raleigh, and Colin Clout seems to offer a shadowed account of aspects of this journey. On one level, therefore, Colin's life mimics that of his creator. On another, it mirrors and inverts it-since, as Richard McCabe comments, 'Colin's voyage out is Spenser's voyage home', just as Colin's

${ }^{15}$ Colin Burrow, 'Spenser's Genres', in The Oxford Handbook of Edmund Spenser, ed. Richard A. McCabe (Oxford: Oxford University Press, 2010), pp. 403-19 (p. 416). 
return home shadows Spenser's setting out again. ${ }^{16}$ Home for Spenser is abroad for Colin, and vice versa. ${ }^{17}$ This structure of doubling is formally registered in the passage from dedicatory address to poetic composition, from 'my house of Kilcolman' to the 'quiet home' (1.686) of 'the shepheards nation' (1. 17). Colin's obsession with a space abroad plausibly encodes Spenser's nostalgia for the country of his birth, but at the same time we have the opening up of Ireland as an alternative space through which feelings of belonging and alienation might also circulate. Here again, therefore, Colin Clout looks forward towards Hofer's Dissertatio, this time in respect of its curious desire to think through the nostalgic affect upside down and back to front, producing familiarity as alienation, shuttling between dislocation and domesticity.

Questions of home and belonging echo through the poem, which twists and turns alarmingly, constantly modifying its attitude to its subject matter. First Colin praises the court of Elizabeth I-Spenser's Cynthia - in contrast to which his (that is, Colin's) native land emerges as an object of deprecation. Then, suddenly, the courtly lifestyle is attacked. Colin frames his discourse as a warning against young shepherds tempted to 'Abandon quiet home' (1. 686). Yet he subsequently goes on to denounce those who give themselves up to a mole-like 'ydelenesse' (1. 761). Mere stasis is not an option either, therefore, although it is an index of the centrality of travel to the poem that this and other sins are described as 'misfaring[s]' (1. 758). Towards the start of the poem the shepherd Thestylis offers a general truth - derived, exotically enough, from Aristotle: 'men vse most to couet forreine thing' (1. 162) ${ }^{18}$ It is, perhaps, the ultimate anti-nostalgic sentiment. It also governs many of the poem's formal procedures. England, Spenser's home, enters the poem only through a screen of alienation effects, as Colin's fellow shepherds punctuate his account with questions that reveal them to be innocents in travel. What is the sea like? (1. 200) Is there really any land other than ours? (1. 291) Is its heaven our heaven? (11. 305-6) Colin Clout's double structure weaves together exoticism and nostalgic longing in a way that

${ }^{16}$ Richard McCabe, 'Edmund Spenser, Poet of Exile', Proceedings of the British Academy 80 (1993), 73-103 (p. 90).

${ }^{17}$ Colin Clout takes the cast of his first major poem, The Shepheardes Calender, and transplants them overseas, where they figure as natives of the place (as their questioning of Colin indicates, they have never been abroad). At one point, Colin refers to himself as having been 'banisht' into a 'waste' (11. 182-83). One could, just about, imagine Colin as a shepherd from the land of Cynthia currently living abroad, in which case his voyage would double rather than mirror Spenser's. His situation is never explicitly defined. However, all the poem's interactions and dialogue point to the second option. With respect to 'banisht', the suggestion is that Colin refers to a romantic banishment (see also 11. 90-91) - hence this aspect of his life at most only alludes to Spenser's 'exile' to Ireland, and, at the level of the poem's plot, Colin is a native of the 'shepheards nation' (1. 17). Rebeca Helfer ingeniously suggests a second reversal, in which Colin Clout might be understood as a prequel to Spenser's earlier poem. 'Spenser paradoxically suggests that this Colin is the earlier incarnation, the figure that the shepherds will later recall in the Calender ... Colin Clout thus both precedes The Shepheardes Calender and follows upon it.' See Spenser's Ruins and the Art of Recollection (Toronto: University of Toronto Press, 2012), p. 232. Helfer's book is also where I first encountered my epigraph, p. 198.

${ }^{18}$ Aristotle, The "Art" of Rhetoric, trans. John Henry Freese (London and New York: William Heinemann and G. P. Putnam's Sons, 1926), p. 351: 'men admire what is remote'. 
logically should be incoherent but that in fact issues from a legible subject position. As Louis Montrose and others have argued, the poem's mirror scenario is a device through which to explore the divided allegiances of an expatriate identity. ${ }^{19}$

Spenser's life and verse are often, and quite understandably, discussed in terms of a thematics of 'exile' ${ }^{20}$ Literally speaking, though, he was nothing of the sort. ${ }^{21}$ On the contrary: as Andrew Hadfield surmises, for Spenser Kilcolman would have represented achievement, "the status of a gentleman, with which came independence and the freedom to write with fewer restrictions ... free of the need to depend on patrons and away from the political intrigues and fashions of court' ${ }^{22}$ It was only after he acquired his 'house' that Spenser resumed a career as a poet in print, interrupted since the publication of The Shepheardes Calender in 1579. Yet the security that Kilcolman represented was precarious. The estate was one of many confiscated from the Earl of Desmond and his followers following an unsuccessful uprising against English authority (1579-83), and this history of dispossession haunts the property. Kilcolman was granted to Spenser under the name 'Hap Hazard', and it was eventually burned down in 1598 during another rising, this time led by the Earl of Tyrone. ${ }^{23}$

Home, we might reflect, is not just a question of location. It also relates to what D. Vance Smith has called the 'household imaginary': the symbolic economies of security and productivity that serve to distinguish domestic from non-domestic space. ${ }^{24}$ Colin Clout modulates not only between home and away but also between scenes of ordered creation and scenes of peril, privation, and waste. When Colin Clout sets sail for the court of Cynthia, we get a description of the sea:

A world of waters heaped vp on hie,

${ }^{19}$ Louis A. Montrose, 'Spenser's Domestic Domain: Poetry, Property, and the Early Modern Subject', in Subject and Object in Renaissance Culture, eds Margreta de Grazia, Maureen Quilligan, and Peter Stallybrass (Cambridge: Cambridge University Press, 1996), pp. 83-130 (p. 97): 'There is an element of equivocation regarding the locus of the poet's homecoming, an equivocation between England and Ireland, that points forcefully towards the paradoxical social identity of the colonist, for whom a departure from his native place has become a return home.'

${ }^{20}$ See in particular McCabe, 'Edmund Spenser, Poet of Exile'.

${ }^{21}$ Joseph Hall skewers the bad faith and posturing that underlay sixteenth-century claims of Irish 'exile' when he presents a prodigal 'malcontent', whose lands are consumed: 'So ships he to the woluish westerne ile, / Among the sauage Kernes in sad exile'. See Virgidemiarum (London: Thomas Creede for Robert Dexter, 1597), sig. D3r. Hall's poem is quoted at the head of an illuminating discussion of Irish exile in Christopher Highley, Shakespeare, Spenser, and the Crisis in Ireland (Cambridge: Cambridge University Press, 1997), pp. 13-14.

${ }^{22}$ Andrew Hadfield, Edmund Spenser: A Life (Oxford: Oxford University Press, 2012), p. 185.

${ }^{23}$ In Book VI of The Faerie Queene, the Kilcolman property may be referenced via a comment about Priscilla's hopes for recovery of her 'hazarded estate'. See Edmund Spenser, The Faerie Queene, revised edition, ed. A. C. Hamilton with Hiroshi Yamashita, Toshiyuki Suzuki, and Shohachi Fukuda (Harlow: Pearson Longman, 2007), VI.iii.12.7.

${ }^{24}$ D. Vance Smith, Arts of Possession: The Middle English Household Imaginary (Minneapolis: The University of Minnesota Press, 2003). 
Rolling like mountains in wide wildernesse,

Horrible, hideous, roaring with hoarse crie. (11. 197-99)

Formless, unknowable, endlessly shifting: the sea as 'wildernesse' represents the very antithesis of home. Colin goes on to ask the Shepherd of the Ocean (Spenser's version of Walter Raleigh) 'Vnder what skie, or in what world we were, / In which I saw no liuing people dwell' (11. 230-31). Twice in this episode the sea is described as a 'world' unto itself. It remakes the familiar coordinates of the world as Colin has known it, and it presents itself as radically inhospitable. Yet almost immediately this wilderness environment begins to be populated with analogues of the pastoral lifestyle Colin has left behind. The sea, we are told, is part of Cynthia's 'Regiment' (1. 234) or rule; the waves are its hills; the fish are its livestock; we see 'heard[s] / Of stinking Seales and Porcpisces' (11. 248-49), farmed by Triton and Proteus. Incomprehension gives way to familiarity, and wilderness is reconfigured as a site of ordered agricultural productivity. In retrospect it becomes clear that even the oceanic mountains that first presented themselves to Colin's imagination only rework the homely Irish landscape that were previously the subject of a song he sang to the Shepherd of the Ocean-a mythographic account of 'Old father Mole ... that mountain gray' (1. 104). Even the most terrifying of environments seems amenable to domestication in Spenser's poem.

III.

The poem's seemingly divergent impulses-longing for home on the one hand, and the ease with which it reduces hitherto alien spaces to familiarity on the other-are really two sides of the same coin. In Spenser as in Hofer, nostalgic affect seems to emerge out of a buried association of familiarity and alienation. But Colin Clout also opens out ways of thinking through what might be at stake politically and historically in these premodern doublings of the idea of home. For Ireland is not simply a source of comforting familiarity in Spenser's poem. It has a secondary aspect, in which it appears as a space marked by sterility, violence, and emptiness. Romantically disappointed, Colin Clout imagines himself banished 'like a wight forlore' into a 'waste' of desolation (11. 182-83); having visited Cynthia's court, he denounces Ireland as a space of 'wayling' and 'wretchednesse', marked by 'grisely famine' and the 'raging sweard' (11. 312, 314). Over and again, we find the landscape of the poem pocketed with these waste spaces. In order to draw out the wider implications of this pattern, I now turn to the thematics of domesticity and of waste in a different product of Spenser's Irish period, the dialogue A View of the Present State of Ireland. Here we see the complexities of premodern nostalgia played out in relation to the history of colonialism in Ireland, ultimately moving towards fantasies of mass starvation and the violent suppression of the Irish populace. On the face of things, the world of the View could not be more different from that of Colin Clout. In both cases, however, Spenser's writing is structured by a nostalgic longing for a place of belonging, and by the impulse towards an ideal of productivity, closely identified with a certain kind of household space.

The View opens by proposing an opposition between waste on the one hand, and the act of plantation on the other. ${ }^{25}$ Ireland is fertile, it is agreed, but its history

\footnotetext{
${ }^{25}$ Andrew Hadfield's biography notes the prominence of 'waste' in Irish affairs and in the View, pp. 203, 216. See also Eamon Grennan, 'Language and Politics: A Note
} 
has been one of waste, in every sense of the word. Clare castle was burnt by 'one of the O-Briens, called Murrough en-Ranagh, that is, Morrice of the Ferne, or waste wilde places'; his plan was 'to make all plaine and waste'. ${ }^{26}$ One of Spenser's speakers, Eudoxus, condemns the 'over-running and wasting of the realme' accomplished by Edward le Bruce in the fourteenth century (p. 25). The other, Irenus, describes how these Scottish forces 'utterly consumed and wasted the land' (p. 27). Irish chroniclers agree that at some point in the distant past a people came out of Spain, 'arrived in the West part of Ireland, and finding it waste, or weakely inhabited, possessed it' (p. 45). And so on. This dismal history provides the backdrop for Elizabethan plans for 'the planting of some good forme or policy' in Ireland (p. 26).

Waste versus planting in turn informs a fundamental concern with home. The View's plans for reducing Ireland to domestic order are underpinned by a protoanthropological account of 'the customes of the Irish' (p. 43). ${ }^{27}$ Irenus depicts the Irish as nomadic pastoralists who follow cattle (the practice is called 'bolleying'), as opposed to proponents of settled domestic livestock agriculture. Spenser is writing here in the tradition of Gerald of Wales, who in the twelfth century had outlined a stadial theory of civilization, arguing that 'man usually progresses from the woods to the fields, and from the fields to settlements and communities of citizens' whilst positioning the Irish on the bottom rungs of this schema:

They are a wild and inhospitable people. They live on beasts only, and live like beasts. They have not progressed at all from the primitive habits of pastoral living ... They use the fields generally as pasture, but pasture in poor condition. Little is cultivated, and even less sown ... The wealth of the soil is lost, not through the fault of the soil, but because there are no farmers to cultivate even the best land. ${ }^{28}$

So too in Spenser. The Scythians' custom, which is also that of the Irish, is to pasture cattle 'upon the mountaine, and wilde waste places' (p. 55). Set against that, 'planting'

on Some Metaphors in Spenser's A View of the Present State of Ireland', Spenser Studies, 3 (1982), 99-110. Grennan argues that the View's primary organising metaphor is the agricultural one, which presents 'the Irish as being in a state of wild nature that needs cultivation to perfect it'; Ireland is in need of 'husbandry' (p. 101). For an account of the 'georgic' character of early modern planters' discourse, see Thomas Herron, Spenser's Irish Work: Poetry, Plantation and Colonial Reformation (Aldershot: Ashgate, 2007), especially pp. 45-68.

${ }^{26}$ A View of the Present State of Ireland. From the First Printed Edition (1633), eds Andrew Hadfield and Willy Maley (Oxford: Blackwell, 1997), pp. 24-25. Further references appear parenthetically.

${ }^{27}$ Margaret T. Hodgen's Early Anthropology in the Sixteenth and Seventeenth Centuries (Philadelphia: University of Pennsylvania Press, 1964) connects Spenser's verse to contemporary representations of the Irish as savage, p. 365.

${ }^{28}$ Gerald of Wales, The History and Topography of Ireland, trans. John J. O'Meara (Harmondsworth: Penguin, 1982), pp. 101-2. The relationship between Spenser and Gerald is discussed in Andrew Murphy, But the Irish Sea Betwixt Us: Ireland, Colonialism, and Renaissance Literature (Lexington: The University Press of Kentucky, 1999). See also Andrew Hadfield, Edmund Spenser's Irish Experience: Wilde Fruit and Salvage Soyl (Oxford: Clarendon Press, 1997), pp. 25-30. 
represents an ideal of domestic husbandry, centred upon the productive household economy.

Andrew Hadfield's recent biography of Spenser is emphatic about the inaccuracy and bad faith that marks this anatomy of the Irish lifestyle. 'If the Irish in Munter were following herds of cattle in the 1590s,' he comments, 'it was in part because their agriculture had been so comprehensively destroyed in the late 1570s and early 1580 s. ${ }^{29}$ In reality, there was little deep-seated difference between sixteenthcentury English and Irish agricultural practice. The simple contrast between English and Irish customs also does scant justice to the mosaic of identities present in Elizabethan Ireland, a variety openly acknowledged at other points in the dialogue. ${ }^{30}$ Nonetheless, page after page of the View pursues the key opposition. Thus, Spenser's interlocutors deplore the way Irish landlords and tenants favour rolling, year-on-year tenancies, and instead recommend extended forms of land tenure because the latter will support an orderly household:

And also it shall be for the good of the tennant likewise, who by such buildings and inclosures shall receive many benefits: first, by the handsomenesse of his house, he shall take more comfort of his life, more safe dwelling, and a delight to keepe his said house neate and cleanely, which now being, as they commonly are, rather swyne-styes then houses, is the chiefest cause of his so beastly manner of life, and savage condition, lying and living together with his beast in one house, in one roome, in one bed, that is, cleane strawe, or rather a foul dunghill. (pp. 83-84)

The 'beastly' home is no home at all; the Irish are simply addicted to a kind of homelessness. Other early modern discussions of Ireland offer a similar analysis. John Davies, for example, identifies tanistry, the Irish tradition of inheritance, as a disincentive to husbandry. Because Irish estates do not descend from father to son there is no reason to improve the land. The Irish 'did neuer builde any houses of Bricke or stone', nor 'plant any Gardens or Orchards, Inclose or improue their Lands, liue together in setled Villages or Townes, nor made any prouision for posterity'. The Irishman is a 'stranger' on his own land, which remains forever 'wast and desolate'. 31 Meanwhile, John Derricke's The Image of Ireland invites wood-dwelling Irishmen to

\footnotetext{
${ }^{29}$ Hadfield, Edmund Spenser: A Life, p. 216.

${ }^{30}$ For an argument about the View having in view Ulster Scots, Old Irish and English as much as native Irish identities, see Willy Maley, "This Ripping of Auncestors": The Ethnographic Present in Spenser's A View of the State of Ireland; in Textures of Renaissance Knowledge, eds Philippa Berry and Margaret Trudeau-Clayton (Manchester: Manchester University Press, 2003), pp. 117-34.

31 John Davies, A discouerie of the true causes why Ireland was neuer entirely subdued (London: [W. Jaggard] for Iohn Iaggard, 1612), sigs. Y3-4v. As Julia Lupton comments, 'by replacing Irish "tannistry", a system of brief corporate land tenure suited to a nomadic, military society, with the English system of inherited territorial land, the settlers were in effect creating "home" in the modern sense of private property'. Julia Lupton, 'Home-Making in Ireland: Virgil's Eclogue I and Book VI of The Faerie Queene’, Spenser Studies, 8 (1990), 119-45 (p. 129).
} 
'submit your selues, vnto your soueraignes lawe'. 'In steade of woodes,' it promises, 'then houses you maie vse, / In steade of Boggs, the Cities at your will.' ${ }^{32}$

In the View, even small details can develop this contrast. Thus, Irenus offers an extraordinarily vehement and exhaustive condemnation of the Irish mantle. The mantle covers a multitude of sins. It allows the criminal to escape detection; it facilitates outlawry; it can be used to carry concealed firearms; it offers a hiding place for illegitimate babies. In this last respect it figures as the antithesis of decent domesticity, 'very unfit for a good huswife to stirre in, or to busie her selfe about her huswifry in such sort as she should' (p. 58). At the same time, though, Irenus objects to the mantle precisely because it is a substitute home: 'a fit house for an out-law, a meet bed for a rebel, and an apt cloake for a thief.' (p. 57). The Irishman can just live in it, regardless of external conditions. 'When it raineth it is his pent-house; when it bloweth it is his tent; when it freezeth it is his tabernacle.' (p. 57) Conversely, when Irenus does discuss the Irish household, it is said to be organised through oppressive or inefficient practices such as the short-term tenancy, or the system of taxation in kind known as coyne and livery (p. 141).

A View of the Present State of Ireland is a text about imposing a certain set of domestic norms upon the Irish; the mantle as anti-house epitomises the problem Irenus imagines himself facing. His desire is to break up family septs and to organize the land into 'English' households, with landlords and tenants comprising a larger estate (p. 120). ${ }^{33}$ But he anticipates stubborn resistance. In principle, the contrast between nomadic pastoralism and household husbandry-however little it reflects the realities of Irish customs - is one in which each alternative might be imagined, protoanthropologically, to be possessed of its own internal rationale. In practice, the former is denounced. Indeed, is only once one grasps the salience of the opposition to that View that one can appreciate the malign logic that animates Irenus' plan for planting the land. This involves garrisoning an army at strategic points throughout Ireland, from which English soldiers will, after a grace-period for surrender, issue out to defeat any remaining opposition. However, Irenus' emphasis falls less on military encounter than on the way his plan will weaponise Irish culture against the Irish. The aim is to reduce the countryside to state comparable to the famine seen in 'these late warres of Mounster', which left the land 'voyde of man and beast' (pp. 101-2). This will afflict the recalcitrant pastoralist with extreme homelessness:

And those 4 garrisons issuing forth, at such convenient times as they shall have intelligence or espial upon the enemy, will so drive him from one side to another, and tennis him amongst them, that he shall finde no where safe to keepe his creete [a creaght or nomadic herd of cattle] in, nor hide himself, but flying from the fire shall fall into the water, and out of one danger into another, that in short space his creete, which is his chiefe sustenence, shall be wasted with preying, or killed with driving, or starved for want of pasture in the woods. (p. 98)

\footnotetext{
32 John Derricke, The image of Irelande (London: [J. Kingston for] Ihon Daie, 1581), sig. K3v.

${ }^{33}$ For a contemporary sketched diagram of a model Munster seignory, made up of farmed plots, mansions, and a village with a church and mill, see Nicholas Canny, Making Ireland British 1580-1650 (Oxford: Oxford University Press, 2001), p. 131. Canny describes it as 'a microcosm of English society ... an English world in an Irish environment' (p. 132).
} 
For this reason Irenus recommends (against normal military practice) fighting in winter, when 'the open enemy having all his country wasted, what by himself, and what by the souldiers, findeth them succor in no place' (p. 99). Spoil the land, Irenus argues, and such a people will defeat themselves. The unvoiced, gleeful taunt that lends imaginative edge to his plan is, roughly, 'so: how do you like your stupid Scythian lifestyle now, then?'

IV.

Such is the logic of English homemaking in Munster. The View is anxiously attentive to the prudent 'husbandry' (p. 95) of the crown's fiscal commitments in Ireland, even as it advocates a policy of household warfare that collapses the opposition between wasting and planting. First Irenus will 'plant' garrisons through the land (p. 106); then they will waste it. Eudoxus can only imagine the 'ruefull spectacles of so many wretched carcases starving, goodly countreys wasted, so huge desolation and confusion' that this policy — of which he entirely approves-will create (p. 102). At least once, the two processes, planting and wasting, meet in a single sentence. It is acknowledged that the best way to defeat Feage McHugh is to pin him down in a single territory, 'either by drawing all inhabitants of those next borders away, and leaving them utterly waste, or by planting garrisons upon all those frontiers about him' (p. 114). The same paradoxes marked Spenser's own career as a homemaker in Ireland. In 1589, his neighbour Lord Roche (who disputed Spenser's claim to the Kilcolman lands) complained that 'by threatening and menacing the said Lord Roche's tenants, and by seizing their cattle, and beating Lord Roche's servants and bailiffs [Spenser] has wasted 6 ploughlands of his Lordships lands'. ${ }^{34}$

The sadism that marks fantasies of an Ireland 'pitifully wasted' (p. 132) with war and famine may seem a long way from Colin Clout's graceful pastoral verse. Indeed, when set against the View, Colin Clout's inversions - the dreamy transference of identities; the antimetabolic sliding of Colin into Edmund and Edmund into Colin; the conversion of what's foreign into home and vice versa-might appear entirely tasteless. Yet one would not want simply to position the former text as the latter's bad conscience. On the contrary: one might just as readily claim the opposite. Colin Clout has more still to tell us about the imaginative spaces out of which premodern nostalgia was to emerge.

An oddity: for a poem so centrally concerned with belonging, Colin Clout is for the most part quite uninterested in actual houses. We have the dedication, signed at Kilcolman; a few brief, metonymic references to the windows, walls, and rooms (1l. 72-26, 776) of Cynthia's court; and a possibly rather startling description of the rejected courtier, 'out of doore quite shit' (1. 709). Other than that, though, the poem is architecturally depopulated. There are topographic sketches of the Irish and English landscapes, and there are parallel accounts of two poetic communities, the 'shepheards nation' (1. 17) and the one at Cynthia's court. The former group is only ever described out of doors; the latter's dwelling is simply unidentified. The lack of specificity that marks Colin Clout - its decoupling of dwelling from building-might be explained with reference to the sixteenth-century understanding of the household as a nexus of persons and possessions as much as a location. It also permits the fluidity that marks the poem's alternation between home and away, underlining the

${ }^{34}$ See Hadfield, Edmund Spenser: A Life, p. 202. 
fact that we are dealing with psychic as much as with physical space. Still: Spenser is not reluctant to engage in domestic ekphrasis elsewhere. One thinks of the palace of Lucifera, the castle of Alma, the temple of Isis, all in The Faerie Queene. The logic of premodern nostalgia in Colin Clout suggests that home must be a space defined through absence and loss. In Spenser's poem it almost seems to have faded away under the pressure of the longing focused upon it.

A second oddity. If the sea in Colin Clout is like a field, fields can resemble the terrifying 'wildernesse' sea. Once arrived in 'Cynthias land' (1. 289), Colin is astonished by the variety and fertility of the landscape, which contrast unfavourably with the privations of his native country:

For there all happie peace and plenteous store

Conspire in one to make contented blisse:

No wayling there nor wretchednesse is heard,

No bloodie issues nor no leprosies,

No grisly famine, nor no raging sweard,

No nightly bodrags [raids], nor no hue and cries;

The shepheards there abroad may safely lie,

On hills and downes, withouten dread or daunger:

No rauenous wolues the good mans hope destroy,

Nor outlawes fell affray the forest raunger. (11. 310-19)

These lines represent the point at which the history of Elizabethan Ireland obtrudes most directly into Spenser's poem. Famine, warfare and outlawry were the products of a policy designed to reduce the land to a state fit for household settlement. Yet here this logic plays itself out differently. In Colin's description of a waste Ireland, England is said to be superior because the shepherd can spend the night lying 'abroad' safely; in Ireland, we infer, he cannot. The existence of the Irish house is implied, although (characteristically) never directly referred to, but its existence is apparently an imposition necessitated by the perils that infest 'hills and downes'. In the View, Ireland must be reformed-laid waste-in order to leave it amenable to the "neat and cleanely' planter's dwelling; in Colin Clout, the implication is that it would be preferable to do without the house altogether, were that only possible. So far as the poem is concerned, shepherding seems every bit as constitutively out of doors as Irish bolleying. ${ }^{35}$

In these ways, the poem's secret desire is for the extramural lifestyle that the prose tract proposes to annihilate; for a home without houses. Does Spenser's poem love waste, then? In a sense, yes. Colin Clout has a curious, even miscellaneous structure. David W. Burchmore has offered an account of the compositional symmetries and echoes that organise the poem. ${ }^{36}$ Very often, though, the logic that guides its movements seems wayward or illegible. It opens by announcing an account of Colin's absence from home, only to veer into a discussion of the Shepherd of the Sea; first the English court is praised, then it is excoriated; Ireland is viewed in a similarly uncertain light. And at the end, seemingly as an afterthought, we get an account of Colin's love for his scornful mistress Rosalind, a conclusion which seems

${ }^{35}$ In fact, sheep would have been central to the domestic economy of Spenser's estate See Hadfield, Edmund Spenser: A Life, p. 218.

36 'The Image of the Centre in Colin Clouts Come Home Againe', Review of English Studies, 28 (1977), 393-406. 
quite disconnected from the poem's primary scenario and main concerns. How are we to relate these lines to what precedes them? Principally, I think, through a thematic of absence. The company of shepherds condemns Rosalind for rejecting Colin Clout, but Colin defends her. 'Not then to her that scorned thing so base,' he declares, 'But to my selfe the blame that lookt so hie' (11. 935-36):

Yet so much grace let her vouchsafe to grant

To simple swaine, sith her I may not loue:

Yet that I may her honour paravant,

And praise her worth, though so far my wit aboue.

Such grace shall be some guerdon for the griefe,

And long affliction which I haue endured:

Such grace sometimes shall giue me some reliefe,

And ease of paine which cannot be recurred. (11. 939-46)

This final episode has been taken to mark the poet's retreat from the tainted environment of Cynthia's court into a world of personal relations and autonomous aesthetic self-fashioning. Really, though, we are not so far from the world of the View. Colin's concluding speech acknowledges that Rosalind's absence is as poetically compelling and productive as her love would be. It is the same story that the nostalgic structuring of the poem, and the household politics of Spenser's Irish writing, have been telling all along. It is, for instance, the same story as that of Cynthia, the foreign queen so divine as to render all speech a perpetual indecorum, incapable of speaking her true worth (11. 344-47, 627); discursively unhoused, praise is driven into flights of similitude (11. 596-611). It is the story of Spenser's 'Hap Hazard' Irish estate, both the fruit of dispossession and the productive site for the circulation of household gifts such as Colin Clout itself, sent to Walter Raleigh with a friendly superscription. It is the story of the Irish mantle, its damnable versatility a response to extreme environmental privation; and of the Shepherd of the Sea's verses, elicited by Cynthia's disdain; and of the wondrous, 'subtile' (1. 217) boat that mysteriously appears to receive Colin Clout and safely carry him over the wilderness sea, almost as if born out of it (11. 212-25). All these moments concern themselves with the thrilling, horrifying creative potential latent within spaces of violence, waste and negation.

Colin Clout presents to its readers a hungry world, replete with insufficiency. Colin's song is listened to with 'greedie listfull eares' (1. 7); his mind 'feed[s]' on the memory of Cynthia (1. 43); the sea is likened to a thousand wild beasts with 'deep mouthes gaping direfull' (1. 202); Ireland is afflicted by famine and overrun with 'rauenous wolues' (1. 318). At the end of the poem, in a neo-Lucretian cosmogony that precedes his praise of Rosalind, Colin names this principle of hunger as love. It is love, we read, which sets the universe in motion and creates order out of nothingness. Love makes cold 'couet' heat, it inspires 'the hungry t'eat', and causes 'voydness to seeke full satietie' (11. 847-50). Thus the world emerged out of darkness. Love is a creative principle, therefore, but, as the language of hunger suggests, it is shadowed by a netherworld of appetite and dearth. Nature, in Colin Clout, does not abhor a vacuum; instead, 'voydness' seeks 'satietie'. Which is it to be: emptiness eliminated in favour of something tangible and constructive, or, conversely, the yearning to take on substance through consumption? It is the same ambiguity that marks both Elizabethan Ireland, the void spaces of which are the precondition for productive husbandry every bit as much as they are its antithesis; and a household logic that mandates waste in order to eradicate waste. The doubling recorded in the phrase 
'coming home again' speaks, in Spenser, to a deep-seated ambivalence in his conception of home. Were it not lost, it would never be necessary to found it.

V.

Nostalgia is not just the longing for home, therefore, but an experience within which the meanings of home are on the move. It is every bit as much a matter of acquiring something as of losing it, and the ecstatic thrill of bereavement that it registers is inextricably bound together with the excitement of new foundations. This reading goes against that developed in the many accounts of contemporary nostalgia, in which it names a profound rootlessness or alienation, conditioned by the experience of western modernity. We might think, for instance, of Martin Heidegger's invocation of 'the homelessness of contemporary man' ${ }^{37}$ or of Georg Lukács' description of the novel as the vehicle for a 'transcendental homelessness'; ${ }^{38}$ or of psychoanalytic claims that the unheimlich, unhomely uncanny speaks distinctively to the psychic underpinnings of modernity. ${ }^{39}$ Plainly perspicacious in so many senses, such readings nonetheless fail to tell the whole story. For what is the novel if not the literary form that more than any other gives expression to the experience of the bourgeois household? And what are the nineteenth and twentieth centuries if not the great eras of nationalism as a global political force? On every front, the development of nostalgia into its most characteristic modern forms is entwined with the formulation of new and insistent structures of community and belonging.

This dual movement is the story told texts by such as Hofer's Dissertatio and Spenser's Colin Clout. One might claim them as specifically premodern accounts of nostalgic longing for this reason: not that they imagine a fundamentally different order of experience, but that they more closely register the contradictions of an incipient modernity than some of their successors seem able to. Contemporary accounts of nostalgia tend to posit the premodern as the space of ontological security that precedes the great defenestrations of modernity. But texts such as Hofer's Dissertatio and Spenser's Colin Clout belong within their own complex narratives of social transformation. In the case of Spenser, we might identify the movement that consolidated royal power in the royal household, and then its outwardly-directed concomitants: a new sense of national identity, a renewed interest in Irish territories and the desire to violently reorganise Irish landholding in the interests of

\footnotetext{
${ }^{37}$ Martin Heidegger, 'Letter on Humanism', in Basic Writings From Being and Time (1927) to The Task of Thinking (1964), trans. David Farrell Krell (London: Routledge, 1993), pp. 213-65 (p. 241). For an analysis of Heidegger's ideas of home-now historical, now existentially-grounded - see Julian Young, 'What is Dwelling? The Homelessness of Modernity and the Worlding of the World', in Heidegger, Authenticity, and Modernity: Essays in Honor of Hubert L. Dreyfus, eds Mark A. Wrathall and Jeff Malpas, 2 vols (Cambridge, Massachusetts and London: The MIT Press, 2000), I, pp. 18-203.

${ }^{38}$ Georg Lukács, The Theory of the Novel: A Historico-Philosophical Essay on the Forms of Great Epic Literature, trans. Anna Bostock (London: Merlin Press, 1971), p. 41.

${ }^{39}$ See for example Mladen Dolar, "I Shall Be with You on Your Wedding-Night": Lacan and the Uncanny', October, 58 (1991), 5-23.
} 
administrative ease of access and maximal productivity. ${ }^{40}$ (Thus Elizabeth I, Spenser's Cynthia, wrote to Charles Blount, Lord Mountjoy in 1602, addressing him as 'Mistress Kitchenmaid' and praising him for the 'faithful care' with which his 'frying pan and other kitchen stuff' had been put to use in reducing the latest generation of Irish rebels to domestic order. ${ }^{41}$ In the case of Hofer, the experiences of servants, residents in homes that were not their own, had remained largely unchanged for centuries; but Swiss soldiers - 'the Gurkhas of early modern Europe' ${ }^{42}$ —were key players in the wars of religion that reconfigured the political map of Europe in the seventeenth century. As recently as 1648, the Swiss confederacy had achieved independence from the Holy Roman Empire as part of the Treaty of Westphalia; the Peasants' War that followed in the 1650 s can be read as a reaction to a movement towards cultural homogenisation and the concentration of power in towns and cities similar to that underpinning Colin Clout ${ }^{43}$ The flicker of doubling and hesitation that attends premodern representations of nostalgia functions, I argue, as a kind of household unconscious. It registers a peripheral awareness of the dual character of novelty and social transformation, gesturing towards the waste spaces that lie at the heart of modernity's productivity and hinting at the subterranean entanglement of moments of displacement and desolation with the sense of belonging. Premodern nostalgia looks both forward and back: back to homes lost, forward to future conversions of imagined 'wilderness' into orderly habitation. ${ }^{44}$ Caught within a causal loop, it feeds the acts of creative devastation that in turn provide the occasion for still more nostalgic longing.

With these thoughts in mind, we might return to Johannes Hofer's Dissertatio Medica de Nostalgia, oder Heimwehe: that ground-breaking yet-it is often implied - excessively simple treatment of a feeling that it barely seems to understand. Older medical doctrines had located the faculty of imagination in the anterior ventricle of the brain. The physiological movement within which Hofer was working broke with this tradition. And so, the sixth thesis of the Dissertatio directs our attention to 'that portion of the brain ... in which such images of objects are represented through a certain motion of animal spirits. This part of the brain is indeed called the center' (p. 384). This 'deepest part of the brain is afflicted constantly from infinite nerve fibres in which the spirits constantly move about in waves' (p. 384). It

${ }^{40}$ On household politics, see David Starkey, 'The Age of the Household: Politics, Society and the Arts c. 1350-1550' in The Context of English Literature: The Later Middle Ages, ed. Stephen Medcalf (London: Methuen, 1981), pp. 225-90.

${ }^{41}$ For an account of these 'kitchenmaid' exchanges, see Leah S. Marcus, 'Elizabeth on Ireland', in Brendan Kane and Valerie McGowan-Doyle eds, Elizabeth I and Ireland (Cambridge: Cambridge University Press, 2014), pp. 40-59 (pp. 57-58).

${ }^{42}$ The epithet is Perry Anderson's. See Lineages of the Absolutist State (London: NLB, 1974), p. 30.

${ }^{43}$ See Yves-Marie Bercé, Revolt and Revolution in Early Modern Europe: An Essay on the History of Political Violence, trans. Joseph Bergin (Manchester: Manchester University Press, 1987), pp. 178-79.

44 On this point, see Lupton 'Home-Making in Ireland', p. 121: 'Home, the paradigmatic object of nostalgia, is a category of experience only fashioned in the alienated, desiring distance from it; it is an imaginary place of original plenitude envisioned only in memory, from which every mature person is in exile ... At the same time, however, "home" indicates the later household, the second nature, built with another and designed in the compensatory image of the first, ideal one.' 
is within this inner zone of incessant motion that that 'Wasting Disease' (p. 380) of nostalgia takes root, and it is this space that is incised and refashioned by the repeated thought of home, carving out familiar pathways from its fluid complexity. In the inmost precincts of the self, at the very seat of the creative imagination: a sea of waste.

University of St Andrews 